\title{
Germinative potential of encrusted seed of tropical forage species
}

\author{
José Rafael de Souza ${ }^{*}$ Janderson de Jesus Lacerda ${ }^{1}$ \\ Otoniel Magalhães Morais ${ }^{2}$ Johon Porto Silva ${ }^{1}$
}

\footnotetext{
'Universidade Estadual do Sudoeste da Bahia (UESB), 45083-900, Vitória da Conquista, BA, Brasil. E-mail: faelmozart@yahoo.com.br. "Corresponding author.

${ }^{2}$ Departamento de Fitotecnia e Zootecnia, Universidade Estadual do Sudoeste da Bahia (UESB), Vitória da Conquista, BA, Brasil.
}

\begin{abstract}
Brazil is the largest producer, consumer and exporter of seeds of forage species, thus the adoption of new technologies for expansion and maintenance of this market is of great importance. The aim of this work was to evaluate encrustation effect on germination potential in seeds of Brachiaria sp. species. The experiment was carried out in Biofabrica laboratory from June to August 2014, in Universidade Estadual do Sudoeste da Bahia, Vitória da Conquista-BA. The experimental design was completely randomized, in a factorial scheme $6 x 2$, with two treatments (with and without coating) and four replications. For germination quality of seeds were evaluated germination and vigor (emergence, emergence speed index, total length of seedling, shoot and root). The encrustation affected positively the germination of seeds in all species tested and encrustation did not affect the total length, shoot and root of the seedlings. Coating after chemical scarification is an alternative to improve germination of the seeds of tropical forage species.
\end{abstract}

Key words: coating, Brachiaria sp., physiological quality.

Potencial germinativo de sementes incrustadas de espécies forrageiras tropicais

RESUMO: O Brasil é o maior produtor, consumidor e exportador mundial de sementes de espécies forrageiras, necessitando da adoção de novas tecnologias para manutenção e expansão deste mercado. O objetivo do trabalho foi avaliar o efeito da incrustação sobre o potencial germinativo de sementes de espécies de Brachiaria sp. O experimento foi conduzido no laboratório da Biofábrica de junho a agosto de 2014, na Universidade Estadual do Sudoeste da Bahia, Vitória da Conquista-BA, em delineamento inteiramente casualizado em esquema fatorial $6 \times 2$, sendo seis cultivares e dois tratamentos (com e sem revestimento). Para determinação da qualidade das sementes, foram avaliados a germinação e o vigor (emergência, índice de velocidade de emergência, comprimento total de plântula, da parte aérea e da raiz). A incrustação afetou positivamente a germinação das sementes de todas as espécies testadas e não afetou o comprimento total, da parte aérea e da raiz de plântulas. O revestimento após escarificação química é uma alternativa que melhora o desempenho germinativo de sementes de espécies forrageiras tropicais.

Palavras-chave: recobrimento, Brachiaria sp., qualidade fisiológica.

\section{INTRODUCTION}

Brazil has great potential to establish a production system of forage species, and the country has an outstanding position in world scenery, which registered significant development in the latest years. The seed production of forage species increased from 27 million tons, in 2010 , to 50 million tons, in 2013 , driven mainly by the acceleration of the meat market and the incentive programs from the federal government (ABRASEM, 2014).

Among several forage species, genus Brachiaria sp. stands out as the most sown in Brazil and highest volume to be exported (LANDERS, 2007). However, the seed quality of this species is not always satisfactory and researches on the subject are rare (PEREIRA et al., 2011). The physiological quality of a seed is an important characteristic, represented by germination and vigor that are essential for rapid establishment of pastures (CUSTÓDIO et al., 2011).

The seed vigor indicates the magnitude of physiological decay and/or integrity of a batch of high germination, which shows their ability on settling on a range of environmental conditions (PESKE et al., 2003). The evaluation of seed vigor aims to complete the standard germination test in order to find differences in physiological quality, distinguishing and classifying according to their field and/or storage performance potential (AOSA, 2002). 
Advances in science and technology in agriculture permits major changes in the production and processing of seeds, in this scenery, seed coating is highlighted, which consists of a dry, inert material and an adhesive to the surface of the seeds. Different treatments can be used aiming to ensure the physiological and physical quality of seeds. Among these treatments is the encrustation, widely used in vegetables and recently used in forage species. The coating represents one of great efficient techniques for initial establishment of pastures, promoting protection, nutrients, growth regulators and plant protection. Also, seed coating facilitates the seeding operation in no-tillage systems (OLIVEIRA et al., 2003).

Despite the increase observed in the use of coated seeds in the latest years, researches aiming to monitor the physiological quality, have taken great importance. Thus, the authors observed that the materials used in seed coating need to be studied, along with the effects on the physiological quality, since some of the compounds used in the process may cause immediate phytotoxic effects on germination or reduce the seed quality (SANTOS et al., 2010).

Given the above, the aim of this work was to evaluate the effect of seed coating on germination in different cultivars of Brachiaria sp.

\section{MATERIALS AND METHODS}

The experiment was carried out in Biofabrica Laboratory, at Universidade Estadual do Sudoeste da Bahia, Vitória da Conquista-BA, from June to August, 2014. Six cultivars of Brachiaria sp. were used (B. decumbens, B. humidicula cv. 'Llanero', B. ruziziensis, B. brizantha cv. 'MG4', B. brizantha $\mathrm{cv}$. 'MG5', B. brizantha cv. 'Marandu'), grown and harvested under the same environmental conditions in 2012/13 harvest, processed and encrusted by Matsuda Minas Company. Seed samples were collected according to Rules for Seed Analysis (BRASIL, 2009) for conventional and coated seeds.

During incrustation process, the company used scarification with concentrated (98\%) sulfuric acid $\left(\mathrm{H}_{2} \mathrm{SO}_{4}\right)$ for 1-2 minutes, afterwards the seeds were coated with polymer (Disco Agro Red L203 at a dose of $160 \mathrm{~mL}$ $100 \mathrm{~kg}^{-1}$ ), fungicide (Carboxin + Thiran 200 $\mathrm{SC}^{\circledR}$ at a dose of $300 \mathrm{~mL} 100 \mathrm{~kg}^{-1}$ seed) and a coating material, which formulation was not disclosed by the company. After treatment, seeds were packed in Kraft paper bags, in air-conditioned rooms at $20^{\circ} \mathrm{C}$, relative humidity of $60 \%$ and absence of light.

The experimental design was completely randomized, in a factorial scheme $6 \times 2$, consisting of six cultivars of forage species and two treatments (with and without coating) with four replications.

In order to evaluate physiological quality, the samples were submitted to the following analyses:

1) Germination test: the treatments consisted of four replications of 100 seeds, which were placed on paper towel in a germination box with dimensions of $11 \times 11 \times 3.5 \mathrm{~cm}$ and moistened with distilled water 2.5 times the mass of the paper (BRASIL, 2009). The containers were identified and randomly maintained in a Biochemical Oxigen Demand (B.O.D) germinator with control of photo and thermoperiod, under alternating temperature of $10-35^{\circ} \mathrm{C}$ associated with 16 hours under dark (lowest temperature) and eight hours under light (highest temperature). Counts were carried out from the seventh day and on the twenty-first the final count was carried out and the results were expressed in average percentage, based on the number of normal seedlings.

2) First count: carried out with germination test, according to the recommendation of BRASIL (2009), with four replications of 100 seeds, consisting in the record of percentages of normal seedlings, seven days after sowing.

3) Emergency rate: a total of 200 seeds (four replicates of 50) per variety were distributed in polystyrene trays with sterilized soil + sandy substrate in a proportion of 1:2. Evaluations were performed at 7 and 21 days after sowing, computing the normal seedlings and the results expressed as percentage of normal seedlings emerged (MAGUIRE, 1962).

4) Emergency rate and emergence speed index of the seedlings: sowing was carried out in substrate soil + sand in the proportion of $1: 2$, in polyethylene trays, using four replications of 50 seeds. After sowing, the trays were kept under field conditions, for 21 days. Two daily evaluations were carried out, number of emerged seedlings until stabilization was computed and emergence speed index was calculated according to MAGUIRE (1962) and the values obtained were transformed in percentage of emergence.

5) Shoot length - the authors used four replications of ten seeds, arranged on the upper third of the germination paper in the shape of a 
roll, moistened with distilled water, 2.5 times the dry mass of the paper towel. The paper rolls were arranged vertically, forming an angle of $90^{\circ}$ with the tray of the B.O.D germinator and kept at a temperature of $27^{\circ} \mathrm{C}$. Twenty one days after the test installation, shoot length of the seedlings was measured using a digital caliper model CD6 CSX-B, and the results were expressed in centimeter $(\mathrm{cm})$.

6) Primary root length: the authors used the same seedlings from each replication used in the previous test, being determined with a digital caliper model CD6 CSX-B, and the results expressed in centimeter $(\mathrm{cm})$.

7) Total length: carried out by the sum of the lengths of the shoot and the primary root, and the results expressed in centimeter $(\mathrm{cm})$ of seedling.

The data were subjected to analysis of variance and the averages were compared by Tukey test 5\% using statistical software Sisvar ${ }^{\circledR}$ version 5.2.

\section{RESULTS AND DISCUSSION}

The study shows significant differences when the seeds were submitted to coating treatment for all the species and varieties tested (Figure 1) and the seeds submitted to encrustation process showed higher germination when they are not encrusted. Species B. brizantha cv. 'Marandu', B. brizantha cv. 'MG5' and $\boldsymbol{B}$. decumbens obtained higher germination indexes with values of 90, 81 and $79 \%$, whereas uncoated seeds showed values of 75,63 and $62 \%$, providing an increase of 17,22 and $21 \%$, respectively.

According to the studies carried out by NOVEMBRE et al. (2006), seeds of B. brizantha reached germination percentage of 77 and $90 \%$, whereas SANTOS et al. (2011) verified 55.25 and $36.25 \%$ for uncoated and coated (by encrustation) seeds, respectively.

Higher indexes of seeds germinated in encrustation may be associated with dormancy breaking promoted by composition of coating material during the process of encrustation. Similar results were reported by MARCHI et al. (2008) when using scarified seeds of Brachiaria brizantha cv. 'Piatã' with sulfuric acid, obtained an increase in germination rate. The authors highlight that presence of oxygen-fixing substances in coating structures reduces the spread of certain elements to the internal tissues of seeds and, therefore, it is associated with dormancy of several grass species including some of the genus Brachiaria sp. (USBERTI \& MARTINS, 2007).

The increase of germination in encrusted seeds may be related to coating quality

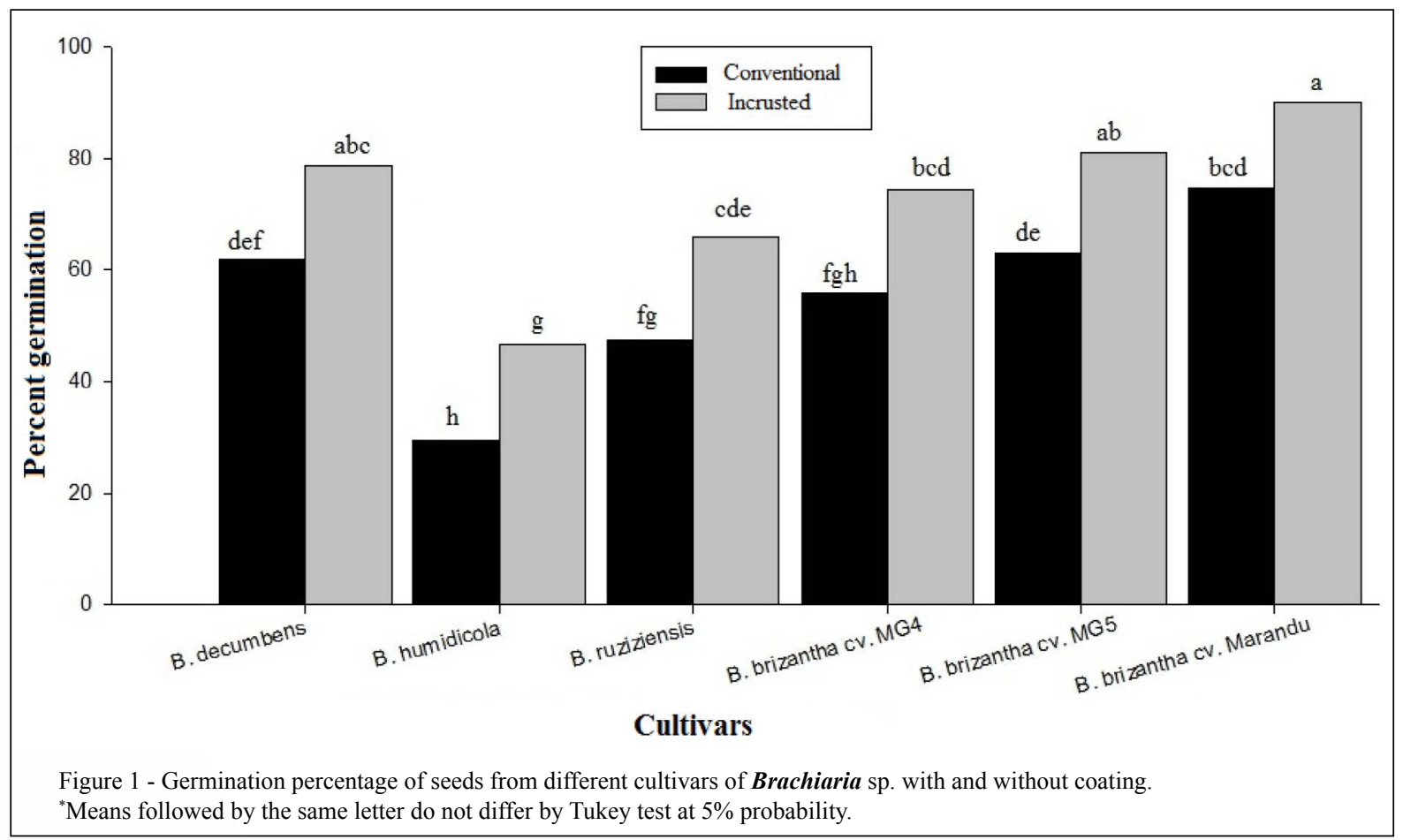

Ciência Rural, v.47, n.2, 2017. 
and divergences among different results with seed coatings are described in literature, also it is attributed to various factors, as the chemical composition of the material, the thickness of the coating layer and, the pre-treatment. However for FERREIRA et al. (2015) seed coating in the hybrid B. brizantha $\mathrm{cv}$. 'Mulato II' reduces viability and speed of germination.

Probably, the chemical scarification treatment associated with the coating material and coating layer, allowed a better mechanical barrier disruption and, therefore, a significant increase in germinative index in encrusted seeds. For BRITES et al. (2011), overcoming dormancy through chemical scarification provided higher percentage of germination for all the grasses studied. The result contrasts with studies carried out by SANTOS et al. (2011), in which seed coating delayed germination of B. brizantha.

In relation to emergence index, the authors verified significant differences among treatments, and encrusted seeds were superior when compared to no encrusted seeds, except for species B. ruziziensis whose encrusted seeds were inferior, showing values of $37.75 \%$ (Figure 2).

Results have showed that, for corn and lettuce crop, variations in coating composition and thickness alter emergence speed index, and it is associated to the development of a physical barrier on the outside of seed making the direct absorption of water and oxygen difficult (CONCEIÇÃO \& VIEIRA, 2008). That pre-treatment of seeds through scarification and film coating may restrict moistening seeds of B. brizantha cv. 'Marandu' (CUSTÓDIO et al. (2011). Some authors confirm that seed coating of Brachiaria sp. is one of the factors to reduce emergence, in this study we verified that coating did not reduce emergence potential, though. The performances of results can be attributed to the composition of coating material and to the chemical scarification treatment during the pre-treatment which possibly did not restrict the ingress of water and gas exchange in the seeds.

During the studies carried out by BRITES et al. (2011), in which they evaluated germination of conventional and coated seeds of tropical forage species, they observed that coated seeds of the genus Brachiaria sp. showed smaller percentage of abnormal seedlings and these data corroborate this study.

Emergence speed index is presented in table 1. It was not observe any significant differences for species B. humidicula and B. brizantha cv. 'MG4' when the coating treatment was applied,

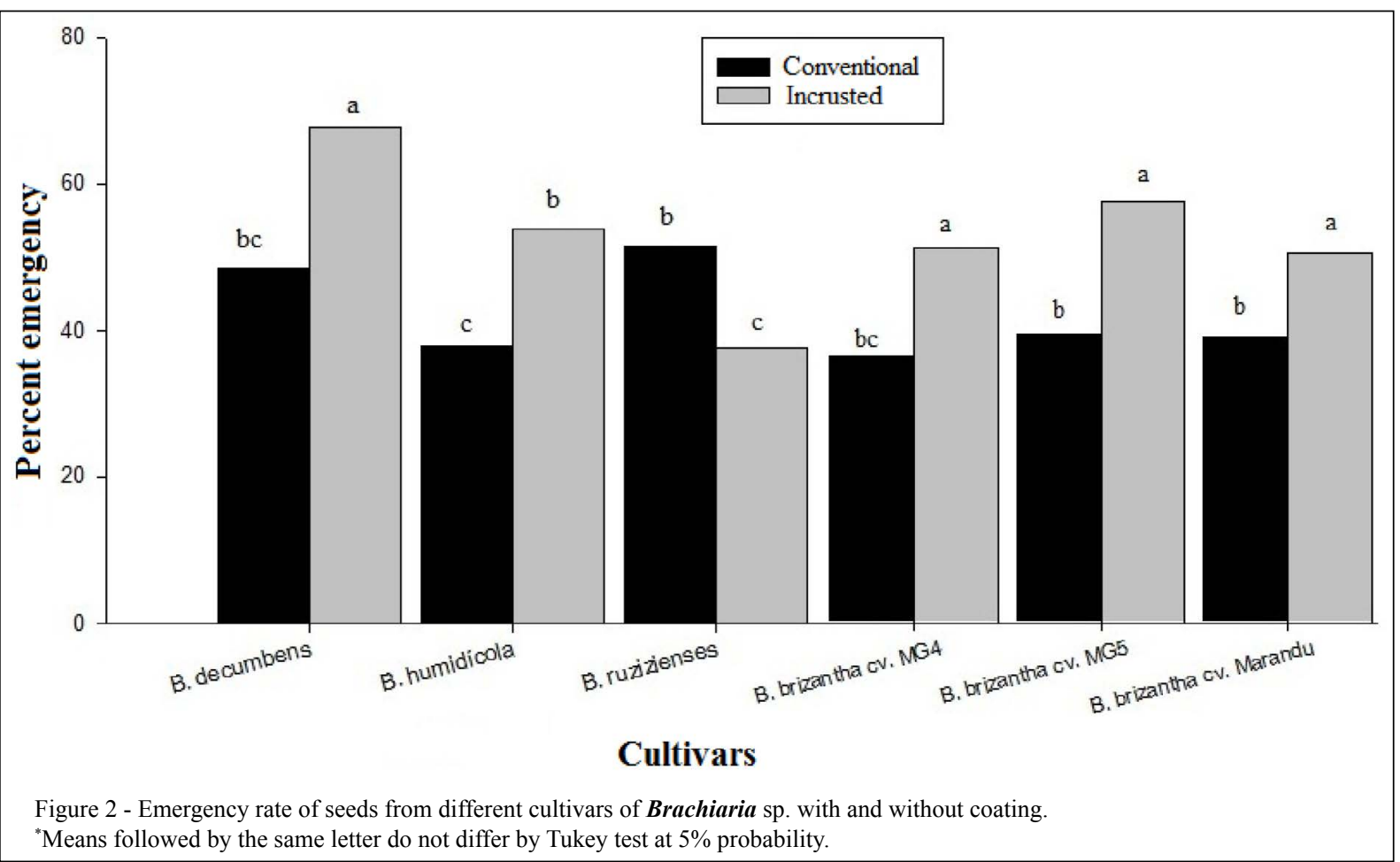

Ciência Rural, v.47, n.2, 2017. 
Table 1 - Emergency speed rate seedlings from seeds of different cultivars of Brachiaria sp. with and without coating.

\begin{tabular}{lcc}
\hline & & Treatment \\
Cultivars & & Uncoated \\
\cline { 2 - 3 } B. brizantha cv. 'MG4' & 2.81 a A & 3.23 a B \\
B. brizantha cv. 'MG5' & 1.93 b B & 3.43 a B \\
B. brizantha cv. 'Marandú' & 2.07 b A & 5.93 a A \\
B. decumbens & 2.51 b A & 3.12 a B \\
B. humudicula & 1.94 a B & 1.44 a C \\
B. ruziziensis & 2.13 b A & 3.27 a B \\
CV (\%) & & 9.27 \\
\hline
\end{tabular}

Means followed by the same capital letter in a column, and small letter on a row, do not differ by Tukey test at $5 \%$ probability.

the highest indexes among species of $\boldsymbol{B}$. brizantha were obtained with encrusted seeds of the cultivars Marandu and MG5 showing values of 5.93 and 3.43 . A trend of increase of emergence speed index was also observed, in encrusted seeds, in relation to the conventional for $B$. decumbens, B. ruziziensis, $B$. brizantha cv. 'Marandú' and B. brizantha cv. 'MG5'. The highest emergence speed index of coated seeds is a desirable characteristic, favors a rapid initial recovery of seedlings and, therefore, better use of abiotic resources.

Previous studies by SANTOS et al. (2010), evaluating the effect of several kinds of coating on the quality of seeds of $\boldsymbol{B}$. brizantha observed that emergence speed indexes were diverse and the lowest rates were observed in seeds coated with sand sand + bentonite + PVA; sand + bentonite + polymer and sand + lime + polymers in studies.
Table 2 presents the results for total length of seedling, length of shoot and root. The study verified no differences between conventional and encrusted seeds. However, VASCONCELLOS et al. (2000), evaluating the effect of coating in sorghum seeds, verified differences in shoot length in seedlings, and MAGALHÃES et al. (1994) showed that seed pelleting influences growth and development of seedling, the magnitude of the effect depending on the cultivars and the kind of coating used.

\section{CONCLUSION}

The encrustation technology used positively affects the percentage of germination and seedling emergence and it does not interfer in total length, length of shoot and root of the seedlings in all the cultivars of Brachiaria sp. tested.

Table 2 - Total length, shoot length and root length of seedlings from different cultivars of Brachiaria sp. with and without coating.

\begin{tabular}{|c|c|c|c|c|c|c|}
\hline \multirow{2}{*}{ Cultivars } & \multicolumn{2}{|c|}{ 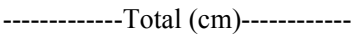 } & \multicolumn{2}{|c|}{-------Shoot lenght $(\mathrm{cm})------$} & \multicolumn{2}{|c|}{----------Root length $(\mathrm{cm})----------$} \\
\hline & Uncoated & Coated & Uncoated & Coated & Uncoated & Coated \\
\hline B. brizantha cv. 'MG4' & 14.9 a A & 16.5 a $\mathrm{A}$ & 8.2 a A & 7.6 a A & 6.7 a $\mathrm{A}$ & 8.9 a $\mathrm{A}$ \\
\hline B. brizantha $\mathrm{cv}$. 'MG5' & 15.6 a $\mathrm{A}$ & 16.7 a A & 7.9 a A & 8.2 a A & 7.6 a $\mathrm{A}$ & 8.4 a A \\
\hline B. brizantha $\mathrm{cv}$. 'Marandú' & 13.7 a A & 15.4 a A & 8.0 a $\mathrm{A}$ & 7.9 a $\mathrm{A}$ & 5.7 a B & 7.4 a A \\
\hline B. decumbens & 15.9 a A & 16.6 a $\mathrm{A}$ & 7.7 a A & 9.5 a $\mathrm{A}$ & 8.2 a $\mathrm{A}$ & 7.1 a A \\
\hline B. humidicula & $11.3 \mathrm{a} \mathrm{B}$ & 9.8 a B & 6.2 a B & 6.2 a B & 5.0 a B & $3.5 \mathrm{a} \mathrm{B}$ \\
\hline B. ruziziensis & 14.7 a A & 16.1 a $\mathrm{A}$ & 7.4 a $\mathrm{A}$ & 9.1 a A & 7.2 a A & 6.9 a A \\
\hline CV $(\%)$ & \multicolumn{2}{|c|}{11.18} & \multicolumn{2}{|c|}{13.73} & \multicolumn{2}{|c|}{13.71} \\
\hline
\end{tabular}

Means followed by the same capital letter in a column, and small letter on a row, do not differ by Tukey test at $5 \%$ probability. 


\section{ACKNOWLEDGMENT}

To Seed Technology Laboratory of Universidade Estadual do Sudoeste da Bahia (UESB) and Matsuda Minas Comércio Ind. 1tda Company for providing the seeds.

\section{REFERENCES}

ABRASEM (ASSOCIAÇÃO BRASILEIRA DE SEMENTES) Sementes é tecnologia. Revista Agroanalysis, v.4, n.2, p.3137, 2014. Available from: <http://www.abrasem.com.br/wpcontent/uploads/2014/04/Mat\%C3\%A9ria-Semente-\%C3\%A9Tecnologia.pdf>. Accessed: Sept. 01, 2014.

ASSOCIATION OF OFFICIAL SEED ANALYSTS. Seed vigor testing handbook. Lincoln, 2002. 105p.

BRASIL, Ministério da Agricultura, Pecuária e Abastecimento. Regras para análise de sementes. Brasília: MAPA/ACS/ Secretaria de Defesa Agropecuária, 2009. 395p.

BRITES, F.H.R. et al. Common seed germination, scarified and covered of different tropical forage species. Bioscience Journal, v.27, n.4, p.629-632, 2011. Available from: <http://www.seer.ufu.br/index. php/biosciencejournal/article/view/11267>. Accessed: Sept. 03, 2014.

CONCEIÇÃO, P.M.; VIEIRA, H.D. Qualidade fisiológica e resistência do recobrimento de sementes de milho. Revista Brasileira de Sementes, v.30, n.3, p.48-53, 2008. Available from: <http://www.scielo.br/scielo. php?script=sciarttext\&pid=S0101-31222008000300007>. Accessed: Sept. 05, 2014. doi: 10.1590/S010 1-31222008000300007.

CUSTÓDIO, C.C. et al. Peliculização de sementes inctactas e escarificadas de Brachiaria brizantha. Pesquisa Agropecuária Tropical, v.41, n.3, p.314-321, 2011. Available from: $<$ http://www. agro. ufg.br/pat>. Accessed: Sept. 01, 2014. doi: 10.5216/pat.v41i3.9146.

FERREIRA, V.F. et al. Qualidade fisiológica de sementes revestidas de braquiária híbrida cv. 'Mulato II'. Revista Agro@mbiente On-line, v.9, n.2, p.161-166, 2015. Available from: $<$ http://revista. ufrr.br/index.php/agroambiente/article/download/2471/1579>. Accessed: Mar. 2016

LANDERS, J.N. Integrated crop management. Roma: FAO, 2007. 92p.

MAGALHÃES, P.C. et al. Efeito de peletização na germinação e desenvolvimento de cultivares de sorgo. Revista Brasileira de Ciências Solo, v.16, n.1, p.20-25, 1994. Available from: <http:// www.alice.cnptia.embrapa.br/handle/doc/477188>. Accessed: Sept. 25, 2014

MAGUIRE, J.D. Speed of germination-aid selection and evaluation for seedling emergence and vigor. Crop Science, v.2, n.1, p.176-177, 1962.
MARCHI, C.E. et al. Progresso e controle da mela-dassementes (Claviceps maximensis) de Brachiaria brizantha. Summa Phytopathologica, v.34, n.3, p.241-247, 2008. Available from: <http://www.scielo.br/scielo.php?script=sciarttext\&pid $=$ S0100-54052008000300007>. Accessed: Sept. 03, 2014. doi: $10.1590 / \mathrm{S} 010054052008000300007$

NOVEMBRE, A.D.L.C. et al. Viabilidade das sementes de braquiária pelo teste de tetrazólio. Revista Brasileira de Sementes, v.28, n.2, p.147-151, 2006. Available from: $<$ http://www.scielo.br/scielo.php?script=sciarttext\&pid $=$ S0101-31222006000200020 $>$. Accessed: Sept. 24, 2014. doi: $10.1590 / \mathrm{S} 0$ 101-31222006000200020.

OLIVEIRA, J.A. et al. Desempenho de sementes de pimentão revestidas com diferentes materiais. Revista Brasileira de Sementes, v.25, n.2, p.36-47, 2003. Available from: <http: //www. scielo.br/pdf/rbs/v25n2/19647.pdf $>$. Accessed: Sept. 14, 2014. doi: 10.1590/S0101-31222003000400006.

PEREIRA, C.E. et al. Armazenamento de sementes de braquiária peletizadas e tratadas com fungicida e inseticida. Ciência Rural, v.41, n.12, p.2060-2065, 2011. Available from: $\quad<$ http://www.scielo.br/scielo.php?script=sci_arttext\&pid $=$ S0103-84782011001200004 $>$. Accessed: Sept. 21, 2014. doi: $10.1590 / \mathrm{S} 0103-84782011001200004$.

PESKE, S.T. (Eds.). Sementes: fundamentos científicos e tecnológicos. Pelotas: UFPel, 2003. 418p.

SANTOS, F.C. et al. Tratamento químico, revestimento e armazenamento de sementes de Brachiaria brizantha cv. 'Marandú'. Revista Brasileira de Sementes, v.32, n.3 p.69-78, 2010. Available from: $<$ http://www.scielo.br/scielo.php? script $=$ sci arttext\&pid=S0 101-31222010000300008>. Accessed: Sept. 24, 2014. doi: 10.1590/S0101-31222010000300008.

SANTOS, L.D.C. et al. Germinação de diferentes tipos de sementes de Brachiaria cv. 'Piatã'. Bioscience Journal, v.27, n.3, p.420-426, 2011. Available from: $<$ http://www.seer.ufu.br/index. $\mathrm{php} /$ biosciencejournal/article/download/8073/7557>. Accessed: Sept. 13, 2014.

USBERTI, R.; MARTINS, L. Sulphuric acid scarification effects on Brachiaria brizantha, B. humidicola and Panincum maximum seed dormancy release. Revista Brasileira de Sementes, v.29, n.2, p.143-147, 2007. Available from: $<$ http://www.scielo.br/scielo.php?script=sci arttext\&pid $=$ S0101-31222007000200020>. Accessed: Sept. 25, 2014. doi: 10.1590/S010 1-31222007000200020.

VASCONCELLOS, C.A. Peletização de sementes de sorgo com calcário e com termofosfato e sua influência na absorção de fósforo e de potássio. Revista Brasileira de Ciências Solo, v.24, n.3 p.545-551,2000. Available from: <http://sbcs.solos.ufv.br/solos/ revistas /v24n3a08.pdf>. Accessed: Sept. 25, 2014. 